\title{
A novel outpatient desensitization protocol for recombinant human erythropoietin allergy in a pediatric patient
}

Jaime S. Rosa ${ }^{1,2^{*}}$, Van B. Vuong ${ }^{2}$, Orly Haskin ${ }^{2,3}$ and Anne Y. Liu ${ }^{1,2}$

\begin{abstract}
Background: Recombinant human erythropoietin, such as epoetin alfa and darbepoetin alfa, is an important therapy for anemia due to chronic renal failure. Allergy to recombinant human erythropoietin and the need for desensitization are rare.

Case presentation: We report here a novel epoetin alfa outpatient desensitization protocol in a girl who developed delayed cutaneous hypersensitivity to subcutaneous epoetin alfa and intravenous darbepoetin alfa. An initial attempt at traditional epoetin alfa desensitization failed, so we created a slower 17-day outpatient desensitization that succeeded and allowed treatment continuation.

Conclusions: This case highlights the notion that delayed-type hypersensitivity to recombinant human erythropoietin can occur as evident by reproducible reactions after repeated exposures and slow outpatient desensitization can be considered when a trial of more rapid induction of tolerance is unsuccessful.
\end{abstract}

Keywords: Hypersensitivity, Epoetin alfa, Desensitization, Pediatric, Child, Drug allergy

\section{Background}

Recombinant human erythropoietin is a mainstay treatment for anemia associated with chronic renal failure. These recombinant products, including epoetin alfa, have amino acid compositions similar to natural human erythropoietin but can still trigger unintended immunologic reactions [1]. Desensitization may be an option to allow continued therapy after development of a drug allergy.

Reports of hives or anaphylaxis immediately following administration of epoetin alfa have suggested IgE-mediated hypersensitivity [1-5]. Some of these patients were able to tolerate epoetin alfa after 3-h or 2-day desensitization $[3,4,6]$. Other reports describe delayed-type hypersensitivity (DTH) rashes [7]. Rarely, acute generalized exanthematous pustulosis can occur weeks after starting epoetin alfa [6]. Slow outpatient desensitization

\footnotetext{
*Correspondence: jsr@iname.com

1 Division of Allergy, Immunology, and Rheumatology, Department of Pediatrics, Stanford University School of Medicine, 269 Campus Drive, CCSR 3215, MC 5366, Stanford, CA 94305, USA

Full list of author information is available at the end of the article
}

to epoetin alfa has not been described. We present a case of a patient who failed a previously published 2-day epoetin alfa desensitization regimen but tolerated epoetin alfa after desensitization over 17 days.

\section{Case presentation}

An 11-year-old girl with end stage renal disease secondary to focal segmental glomerulosclerosis was admitted for bilateral nephrectomies and initiation of hemodialysis. 6 weeks prior to hospitalization, the patient was started on subcutaneous epoetin alfa. After three injections, she developed a pruritic rash that gradually improved over 2 weeks. On this admission, she had a hemoglobin concentration of $6.5 \mathrm{~g} / \mathrm{dL}$. Epoetin alfa was switched to intravenous darbepoetin alfa due to the reported rash. The following day, she developed a diffuse, pruritic, maculopapular rash (Fig. 1). Eosinophil count was 210 cells $/ \mu \mathrm{L}$, and aspartate and alanine aminotransferases were within the normal ranges. Hydroxyzine alleviated her symptoms, and allergy consultation was requested. 


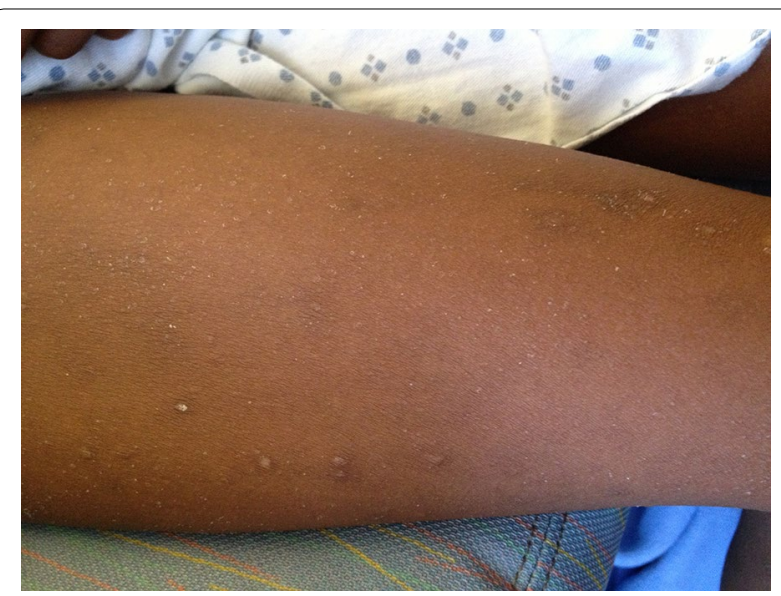

Fig. 1 The patient developed an intensely pruritic, maculopapular rash during the second day of the first desensitization protocol

Since the patient required recombinant human erythropoietin to avoid the need for recurrent blood transfusions, we followed a previously published two-day epoetin alfa desensitization protocol reported in an adult who had experienced maculopapular eruptions after receiving epoetin alfa [6]. Our protocol was adjusted for the pediatric patient's weight to achieve a target dose of 700 IU (Table 1). On day one of desensitization, 7, 14, 28, and 56 IU of epoetin alfa were administered at 6-h intervals. Within $6 \mathrm{~h}$ of the $56 \mathrm{IU}$ dose, she developed a pruritic, maculopapular rash, improved with hydroxyzine, and she was started on prednisone $10 \mathrm{mg}$ daily with subsequent rash resolution. The protocol was then modified to lengthen the course, with 48-72 h intervals between each escalating dose, carried out in the outpatient setting (Table 2). After hospital discharge, the patient started the prolonged desensitization, resuming at the previously tolerated dose of $28 \mathrm{IU}$ on day four counting from the first day of initial desensitization. $2 \mathrm{~h}$ later, she developed itching in her lower back, thighs, and forearms, but there

Table 1 Original inpatient 2-day slow desensitization protocol

\begin{tabular}{lcc}
\hline Day & Dose (IU)* & Cumulative dose (IU) \\
\hline 1 & 7 & 7 \\
1 & 14 & 21 \\
1 & 28 & 49 \\
1 & $56^{\dagger}$ & 105 \\
2 & 112 & 217 \\
2 & 224 & 441 \\
2 & 259 & 700 \\
\hline
\end{tabular}

* Doses were administered every $6 \mathrm{~h}$

+ Desensitization terminated due to reaction was no visible lesion. Hydroxyzine $25 \mathrm{mg}$ ameliorated the symptom. On day seven, she received 56 IU of epoetin alfa without further complaints, and thereafter she continued to tolerate escalating doses according to schedule (Table 2). 2 days after achieving the target dose of 700 IU, the prednisone was discontinued. Her eosinophil counts and liver enzymes were monitored at least once weekly during the desensitization without abnormalities (Table 3). The patient continued to tolerate epoetin alfa at 700 IU 3 days a week, which was increased several weeks later to 850 IU 3 days a week. 2 months later, she missed several doses then received intravenous epoetin alfa during peritoneal catheter revision; the next day she developed a papular rash, fever, and eosinophilia, which resolved after several days of low dose prednisone and resumption of her regular subcutaneous dosing. Subsequently, the patient experienced no other adverse effects until this therapy was stopped when she received a deceased-donor renal transplant a year later.

\section{Discussion}

Immediate hypersensitivity reactions to human recombinant erythropoietin are characterized by bronchospasm, urticaria, cyanosis, angioedema, vomiting, abdominal discomfort, and hypotension [1-3] occurring within minutes to a few hours of administration. In contrast, our pediatric patient experienced a maculopapular rash $24 \mathrm{~h}$ after drug administration. The differential diagnosis for her reaction included IgG-mediated hemolytic anemia (such as pure red cell aplasia) as the patient remained anemic while on recombinant human erythropoietin therapy $[5,8]$. However, anti-epoetin alfa and anti-darbepoetin alfa antibodies were non-detectable when biosensor immunoassay was offered and performed by the manufacturer (GE Healthcare-Biocare, Uppsala, Sweden) [9]. Furthermore, she did not have features that would favor drug reaction with eosinophilia

Table 2 Modified outpatient 17-day slow desensitization protocol

\begin{tabular}{lc}
\hline Day & Dose (IU)* \\
\hline 1 & 7 \\
1 & 14 \\
4 & $28^{\dagger}$ \\
7 & 56 \\
10 & 112 \\
12 & 224 \\
15 & 450 \\
17 & 700 \\
\hline
\end{tabular}

* Doses were administered every 48-72 h

+ Continued from first trial of desensitization 
Table 3 Laboratory testing results at different time periods of the patient's presentation

\begin{tabular}{|c|c|c|c|c|c|}
\hline Laboratory testing & $\begin{array}{l}\text { Baseline before recom- } \\
\text { binant human erythro- } \\
\text { poietin }\end{array}$ & $\begin{array}{l}\text { Day } 2 \text { of initial reaction } \\
\text { to intravenous darbe- } \\
\text { poetin alfa }\end{array}$ & $\begin{array}{l}\text { Day } 2 \text { of failed 2-day } \\
\text { desensitization to epo- } \\
\text { etin alfa }\end{array}$ & $\begin{array}{l}\text { During modified } \\
\text { desensitization (at } \\
112 \text { IU daily dose) }\end{array}$ & $\begin{array}{l}\text { One month } \\
\text { after desensiti- } \\
\text { zation }\end{array}$ \\
\hline Hemoglobin (g/L) & 7.8 & 7.0 & 6.7 & 6.0 & 9.2 \\
\hline Hematocrit (\%) & 22.3 & 20.7 & 19.5 & 18.6 & 27.0 \\
\hline $\begin{array}{l}\text { White blood cells } \\
\text { (cells/ } / \mu \mathrm{L})\end{array}$ & 9100 & 10,400 & 13,100 & 13,300 & 10,200 \\
\hline Neutrophils (cells/ $\mu \mathrm{L}$ ) & 3600 & 5700 & 6100 & 8900 & 9200 \\
\hline 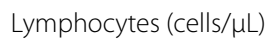 & 3600 & 1300 & 2800 & 2400 & 600 \\
\hline 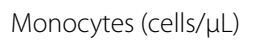 & 400 & 1000 & 1300 & 1000 & 200 \\
\hline Eosinophils (cells/ $\mu \mathrm{L}$ ) & 1400 & 2400 & 3000 & 900 & 200 \\
\hline Basophils (cells/hL) & 100 & 0 & 0 & 100 & 0 \\
\hline $\begin{array}{l}\text { Aspartate aminotrans- } \\
\text { ferase (IU/L) }\end{array}$ & 34.0 & NM & 14.0 & 15.0 & NM \\
\hline $\begin{array}{l}\text { Alanine aminotrans- } \\
\text { ferase (IU/L) }\end{array}$ & 33.0 & NM & $<15$ & 15.0 & NM \\
\hline $\begin{array}{l}\text { Blood urea nitrogen } \\
\text { (mg/dL) }\end{array}$ & 51.0 & 54.0 & 59.0 & 9.0 & 30.0 \\
\hline Creatine (mg/dL) & 3.2 & 8.1 & 12.9 & 11.6 & 7.5 \\
\hline
\end{tabular}

NM not measured

and systemic symptoms (DRESS), acute generalized exanthematous pustulosis, Stevens-Johnson syndrome, or other drug eruptions. Although the family declined a skin biopsy for confirmation due to the invasive nature of this procedure, the clinical presentation was consistent with DTH. Therefore, we followed a previously published desensitization protocol [6], which failed to induce tolerance to the medication for our patient, whose rash recurred. Because of the relatively benign nature of her allergic response, we opted to try a novel desensitization protocol, with longer intervals between dose escalations, which can increase the likelihood for successful desensitization [7].

Hypersensitivity to recombinant human erythropoietin and treatment with rapid desensitization have been reported $[1,6,8]$, but outpatient desensitization for DTH has not, particularly after failed rapid desensitization. Our protocol features slower dose escalation (17 days), low dose prednisone, and outpatient setting. Whether the corticosteroid contributed to tolerance induction in this case is unknown, but its discontinuation shortly thereafter demonstrated that it was not necessary for maintenance of tolerance.

\section{Conclusions}

Two key points make this case noteworthy. First, we proved an antigen-specific allergy by provoking the same reaction upon re-administration, which is infrequently done in case reports of successful desensitization. Often the severity of reaction makes physicians reluctant to rechallenge. In this case, her reactions from the initial desensitization attempt and subsequent exposure to an intravenous bolus after missing a few subcutaneous doses provided good evidence of a true allergy. Second, the slow desensitization was successful in a patient who had failed rapid desensitization. This bolsters the concept that desensitization protocols must be tailored to the patient's reaction and any single protocol may not be universally applicable. Outpatient desensitization is a viable option for selected patients who have non-life-threatening DTH to epoetin alfa and require its use, particularly if rapid desensitization is unsuccessful.

\section{Abbreviations}

DTH: delayed-type hypersensitivity; g/dL: gram per deciliter; cells/ $\mu \mathrm{L}$ : cells per microliter; IU: international unit; DRESS: drug reaction with eosinophilia and systemic symptoms.

\section{Authors' contributions}

All authors provided clinical care to the patient and edited the manuscript. JSR and VBV collected the clinical data and drafted the manuscript. AYL also collected clinical data. All authors read and approved the final manuscript.

\section{Author details}

${ }^{1}$ Division of Allergy, Immunology, and Rheumatology, Department of Pediatrics, Stanford University School of Medicine, 269 Campus Drive, CCSR 3215, MC 5366, Stanford, CA 94305, USA. ${ }^{2}$ Lucile Packard Children's Hospital Stanford, Stanford Children's Health, Palo Alto, CA 94304, USA. ${ }^{3}$ Division of Nephrology, Department of Pediatrics, Stanford University School of Medicine, Stanford, CA 94305, USA.

\section{Acknowledgements}

We are grateful for this patient and family's trust in our care and their approval to share her interesting clinical course to the medical and scientific community. Additionally, we appreciate our colleagues_-physicians, nurses, allied health care professionals-for providing excellent care to this patient. Lastly, we thank Kate Mulligan for assisting in the preparation of this manuscript. 


\section{Competing interests}

The authors declare that they have no competing interests.

\section{Availability of data and materials}

The datasets supporting the conclusions of this article are included in the article (Tables 1, 2, 3; Fig. 1)

\section{Consent for publication}

Written assent and consent to publish this report was obtained from the patient and her mother, respectively. A copy can be made available if required.

\section{Ethics approval and consent to participate}

The presented data are part of our clinical work and there is no ethical conflict. The authors, patient, and guardian fully authorize the publication of this clinical case.

\section{Funding}

No external funding was obtained.

\section{Publisher's Note}

Springer Nature remains neutral with regard to jurisdictional claims in published maps and institutional affiliations.

Received: 22 September 2017 Accepted: 25 January 2018

Published online: 12 March 2018

\section{References}

1. Garcia JE, Senent C, Pascual C, Fernandez G, Perez-Carral C, Diaz-Tejeiro $R$, et al. Anaphylactic reaction to recombinant human erythropoietin. Nephron. 1993;65(4):636-7.
2. Jabr Fl, Taher A. Recurrent skin reaction secondary to darbepoetin alfa for two months in a patient with chronic lymphocytic leukemia. Am J Hematol. 2007;82(3):245.

3. Aziz N, Luna C, Mirza F, Tobin M. Anaphylactic shock at the end of hemodialysis. Sem Dial. 2015;28(6):661-4.

4. Tahan F, Akar HH, Dursun I, Yilmaz K. Desensitization of darbepoetinalpha: a case report. Eur Ann Allergy Clin Immunol. 2013:45(5):176-7.

5. Weber G, Gross J, Kromminga A, Loew HH, Eckardt KU. Allergic skin and systemic reactions in a patient with pure red cell aplasia and anti-erythropoietin antibodies challenged with different epoetins. J Am Soc Nephrol. 2002;13(9):2381-3.

6. Ruano FJ, Garcimartin MI, Vazquez de la Torre M, Blanca M, Canto G. Desensitization of epoetin-alpha in a confirmed case of acute exanthematic pustulosis. Allergy. 2009;64(12):1797-8

7. Scherer K, Brockow K, Aberer W, Gooi JH, Demoly P, Romano A, et al. Desensitization in delayed drug hypersensitivity reactions - an EAACI position paper of the Drug Allergy Interest Group. Allergy. 2013:68(7):844-52.

8. Casadevall N, Nataf J, Viron B, Kolta A, Kiladjian JJ, Martin-Dupont P, et al. Pure red-cell aplasia and antierythropoietin antibodies in patients treated with recombinant erythropoietin. N Engl J Med. 2002;346(7):469-75.

9. Mytych DT, La S, Barger T, Ferbas J, Swanson SJ. The development and validation of a sensitive, dual-flow cell, SPR-based biosensor immunoassay for the detection, semi-quantitation, and characterization of antibodies to darbepoetin alfa and epoetin alfa in human serum. J Phar Biomed Anal. 2009:49(2):415-26.

\section{Submit your next manuscript to BioMed Central and we will help you at every step:}

- We accept pre-submission inquiries

- Our selector tool helps you to find the most relevant journal

- We provide round the clock customer support

- Convenient online submission

- Thorough peer review

- Inclusion in PubMed and all major indexing services

- Maximum visibility for your research

Submit your manuscript at www.biomedcentral com/submit

C Biomed Central 